\title{
Study About the Management of Medical Waste and Non Medical Waste in Kwaingga Public Hospital, District Keerom, Jayapura
}

\author{
Hesty Tumangke \\ Faculty of Public Health, Cenderawasih University, Jayapura City, Indonesia
}

Email address:

hestytumangke@yahoo.com

\section{To cite this article:}

Hesty Tumangke. Study About the Management of Medical Waste and Non Medical Waste in Kwaingga Public Hospital, District Keerom, Jayapura. International Journal of Health Economics and Policy. Vol. 4, No. 4, 2019, pp. 151-157. doi: 10.11648/j.hep.20190404.15

Received: October 11, 2019; Accepted: November 23, 2019; Published: December 7, 2019

\begin{abstract}
Kwaingga Public Hospital is categorized as type C hospital because there are several aspects need to be improved for management and quality in order to fill the standard from Ministry of Health. Especially for a medical waste management, hospital staffs said that an incinerator has potential to explode due to bad structure because its pillar consists wood. This study aimed to observe the management of medical waste and general waste in Kwaingga Public Hospital. This study is qualitative study where the population is all staffs that work in Kwaingga Public Hospital, and the study sample is six Hospital staffs including hospital director, planning division, treasurer, and sanitarians. They have been deep interviewed and recorded. Study took visual documentations. There are 20 trashes distributed in hospital for daily waste and it is end in a small landfill in hospital backyard. This managed by 10 cleaning services and the staffs said that that number is still inadequate. Sanitarian staffs are six and they all have background sanitation diploma, but they still have overload tasks and they don't get any training for development yet, the last training was in 2012. There are incinerator, wastewater treatment plant, septic tank, filtration for wastewater, and an old incinerator; there is no machine for destroyed needles. Unfortunately, the incinerator was rarely to use since its structure is bad and has potential to explode; also diesel fuel cost is expensive, so the medical waste burned manually including needles. Similarly, wastewater treatment plant is rarely used due to electricity cost, so it only runs if the wastewater is full. Wastewater treatment plant had bought from Local government Revenue costing 4.5 billion rupiah. Salary for contact staffs and cleaning services are also from local government revenue. Therefore, local government revenue must be increased its allocation for hospital waste management.
\end{abstract}

Keywords: Hospital Waste, Management, Kwaingga Public Hospital

\section{Introduction}

According to literature review by Ali et. al. 2017. with tittle "Hospital Waste Management in Developing Countries", in developing countries still there are many problem about waste management especially management of hazardous waste. Poor sanitation implementation toward hospital waste management can cause in the mixing hazardous waste and general waste and this leads to increase cost for hospital waste management [1].

Report from WHO states that among 22 developing countries there are about $20-60 \%$ healthcare facilities that do not implement proper healthcare waste management. In those countries also regulations toward medical waste management is lacking and poorly enforced [4].

Based on the Indonesia Health Ministry Report 2015; only $10.29 \%$ hospitals in Indonesia have medical waste management that has fulfilled the Health Ministry standard. There are 11 provinces that practice poor medical waste management, and one from those provinces is Papua Province where Kwaingga Hospital is located. In addition, there is 10 to $25 \%$ hospital waste in those province identified as hazardous waste that will cause several health problem such as HIV, Typhoid, Malaria, Cholera, skin diseases, and hepatitis [15].

In developing countries there is also problem such as lack of color coding and poor segregation practices and this causes incident such as needle stick injuries. Training 
regarding safety medical waste management in developing countries is still limited and this cause lack knowledge about the dangers of inhalation and skill exposure of chemical from medical waste among healthcare workers [1].

Kwaingga Public Hospital that located at Arso District, Keerom Region has categorized as hospital type D from Indonesia Ministry of Health, but now the team of Kwaingga Public Hospital makes an effort to upgrade it's quality to type C. However from the government Kwaingga region's point of view, this hospital is already in the category of Type $\mathrm{C}$, and needs to increase management and quality in order to meet the standard from Indonesia Ministry of Health.

According to observational interview, there is no final disposal site for medical waste and daily waste in Kwaingga Hospital; thus, medical waste only filled at hospitral backyard. This problem caused by broken incinerator, so medical waste is filled or burns every two weeks. This incinerator bought in 2012 and sanitarian staff said that using this incinerator is very dangerous due to its structure contained wood that can easily burning. Furthermore, Kwaingga hospital already has wastewater treatment plant from 2013 and it is operating well until now.

Medical waste and non-medical waste in Kwaingga Hospital really need adequate human resources. Based on researcher's observational interview, sanitarian staff and staffs whom responsible for hospital waste are 6 staffs with sanitarian and environment education background. However, several staffs said that they work multiple responsible or overlap worksheet. Same as training about hospital management did not conduct yet; the latest training was conducted in 2012. They also said that hospital already made Operational Procedure Standard for medical waste and daily hospital waste

Therefore, based on the several cases that been mention, researcher want to observe how Medical Waste and Non Medical Waste management in Kwaingga Hospital. Also, this research aims to know what factors that cause hospital waste management does not implement well, seeing form human resources, financing, and facilitation aspects.

\section{Method}

This study is descriptive study with qualitative method where research variables are several inputs for hospital waste management such as human resources, facilitations regarding waste management especially medical waste, financing, and factors that restricting the implementation of Standard Operational Procedure for the hospital waste management (medical waste and non medical waste management). This study also aims to analyze barriers in implementing hospital waste management in Kwaingga Hospital. The population of this study is all staffs that work in Kwaingga Public Hospital, and the study sample are six Hospital staffs including hospital director, planning division, treasurer, and hospital sanitarians. They have been deep interviewed and recorded. Study also took visual documentation for the condition of incinerator, landfill and wastewater treatment plant.

\section{Result}

\subsection{Resources That Related to the Medical Waste and Non-medical Waste Management}

Human Resources

From deep interview, study has found that staffs for nonmedical waste giving to third person who responsible for providing cleaning services for non medical waste management. There are 10 staffs that have responsible to lifted, collected, and burned it everyday.

"Non-medical waste, there are 10 cleaning services; they all from third person who been contracted (Informant 1)".

However from quantity, informant thinks that this is still inadequate where normal amount that needed are 20 cleaning services. This is because financial issue according to the interview.

"We need more cleaning services because we have many rooms, 12 staffs are still limited. We need 20 cleaning services (Informant 4).

Same as sanitarian staffs for medical waste, they are 6 employees and they have bachelor from sanitarian and health environment. They have responsible for implementing and monitoring medical waste and non-medical waste management. They are also responsible for putting and filling medical waste to incinerator and running the wastewater treatment plant for liquid medical waste.

"There are 6 staffs; they graduated from health environment specification (informant 2)".

On the other hand, there are different opinions among informants about amount of sanitarian employees. One of informants said that quantity of sanitarian staffs is adequate and they must work maximal. In fact, some of the staffs still have another responsible such as treasurer for hospital logistic; therefore, they have over workload. Director of Kwaningga Hospital said that this hospital still needs more health providers with health environmental specification.

"We need more staffs with health environment specification (Informant 4)”.

In addition, training for sanitarian human resources improvement does not conduct frequently. There are many kind of training that sanitarian at Kwaingga Hospital need such as standard for using and benefit of self-protection devices and training for capacity building for sanitarian staffs and cleaning services. Only one staff that ever attending training in Bandung City, and it was four years ago, the training was about B3 or Dangerous and toxic materials. There is no other training currently, and they said that they also need training about how to make report because until now there is no report to Environment Department from Kwaingga Hospital due to lack of skill among staffs regarding a method of making routine report of hospital waste management.

"There was once training about dangerous and toxic materials in Bandung, 2012, and after that there is no more other training. There are five sanitarian staffs that did not get any training yet (Informant 2)".

"We also need training for making report; we did not write 
the report because we don't understand, so we did not handing the report that actually must handing every three months to Environment Department" (Informant 1).

\subsection{Facilitations for Medical Waste and Non Medical Waste Management}

Facilitations for supporting medical waste and nonmedical waste in Kwaingga Hospital are already provided such as incinerator, wastewater treatment plant, and septic tank for liquid waste from lab and surgery room. Also, there are two temporary land filled for medical waste and non medical waste at the hospital backyard and a small traditional burning stone for medical waste with size 1 x 1 meter. However, there are still facilitations that do not provide like permanent/final landfilled, machine for destroying needless because sometimes staffs found difficulty for run the incinerator, and device for room sterilization.

"Facilitations for medical waste are incinerator and wastewater treatment plants; facilitation that we don't have is room sterilization, we need to sterilize room every time new patients come (Informant 1)"

There are many barriers regarding availability of utilities for medical waste such as the construction of incinerator contains with wooden pole; it must be iron pole; therefore, it is easy burning. Diesel fuel cost for operating the incinerator is expensive; electricity cost for run the wastewater plant is expensive, so it does not run everyday, staffs waiting until it is full then it will run again. Moreover, hospital also needs more facilitation for instance room sterilization device, permanent landfilled for medical and non-medical waste, machine for destroying used needless, and truck to carry daily hospital waste to final landfilled at Kwainngga district's landfilled. Another problem is the self-protection device is provided but staffs did not used it.

"It's already three month waste was accumulated at hospital backyard; and needless still stacked there. Incinerator was provided in 2012 and it was bought by district health office and it did not use for three month. For liquid waste, the barrier is electricity cost, it is run out very fast and button for channel the waste from lab to septic tank was broke, and we had tried to fix it (Informant 2)".

Utilizations for non-medical waste as trashes were provided. We ever tried to carry it to district landfilled, but we have a problem because regarding permission from regional government. On the other hand, making specific landfilled for this hospital need billion of money and governor has to contribute; that is why we made hospital temporary landfilled for daily waste and medical waste at the hospital backyard. We tried to carry our hospital waste to the district landfilled but truck driver did not want because it was waste from hospital (Informant 4).

Table 1. Kwaingga Hospital Waste Facilities.

\begin{tabular}{llll}
\hline No & Type of Waste & Name of Facility & Amount \\
\hline 1 & Non Medical Waste & Trash Can & 20 \\
2 & Non Medical Waste & Temporary Landfilled & 1 \\
3 & Medical Waste & Incinerator & 1 \\
\hline
\end{tabular}

\begin{tabular}{llll}
\hline No & Type of Waste & Name of Facility & Amount \\
\hline 4 & Medical Waste & Temporary landfilled & 1 \\
5 & Medical Waste & Wastewater Treatment Plant & 1 \\
6 & Medical Waste & Septic Tank & 1 \\
7 & Medical Waste & Wastewater Filtration & 1 \\
8 & Medical Waste & An Old Incinerator & 1 \\
\hline
\end{tabular}

A method that Kwaingga Hospital uses already according to the Standar Operational Procedure, for example incinerator for solid medical waste and Water waste treatment plant for liquid medical waste. Similarly, the non medical waste that has final temporary landfilled at hospital backyard where garbage is collected everyday and carry to the temporary landfilled.

Liquid waste such as blood channels to the septic tank and water waste treatment plant. We have water waste treatment plant behind the hospital and its filtration already matched with the standard (Informant 1).

Liquid waste accommodates in storage. Liquid waste is not yet full, it only from laboratory and surgery room; surgery room has its own septic tank, and the volume of liquid waste is not full yet because surgery service is rarely and it is just small surgery. The non-medical waste transporting does not has obstacle (Informant 2).

There is septic tank that channel to incinerator, and that liquid waste precipitated first with antiseptic. Liquid waste has been processed in incinerator, but first we collect the waste in septic tank with antiseptic. The method for non medical waste is collected and burned, we've tried to carry it to the district permanent landfilled but we cannot bring it due to permission from local government (Informant 4).

Furthermore, there are many barriers on the method of Kwaingga Hospital waste management where there is inadequate fund for operational cost. For example incinerator for three months did not run due to expensive cost of diesel fuel. Also, part of incinerator's pillar structure made from wood that is why it is easily burning, that scared the sanitarian staffs where we know that based on the standard, the incinerator's pillar structure must be made from iron, so it will not easily burned. Similarly, Wastewater treatment plant did not frequently run because of it needs huge capacity of electricity that is expensive.

Incinerator has bad construction; it is easily burned because its pillar structure made from wood. So if not burned, hospital waste will be acquired (Informant 1).

We are intensely used manual way that is burned. Kwaingga Hospital has Waste water treatment plant but the problem is expensive electricity cost due to using huge electricity power, so waste water treatment plant runs four hours per day. This waster water treatment plant costs 4.5 billion rupiah. This runs if only it is full. If pipes are full then it will be channeled and running. Sometime in one day it is not full, so we wait until it is full then aspirated (Informant 4).

\subsection{Financing for Waste Management}

The Procurement of devices majority come from grant, for instance incinerator is one of grant from Indonesia Ministry 
of Health. Wastewater treatment plant had bought from Local government Revenue (APBD) costing 4.5 billion, however those machines need operational cost such ass electricity cost and diesel fuel. Salary for contact staffs and cleaning services are also from local government revenue. Similarly, operational cost such as electricity and diesel fuel cost are from local government revenue, but this operational cost often do not enough because the budget that we proposed did not same as the realization that giving to the Kwaingga Hospital.

"Financing for waste management, incinerator is a grant from Ministry of Health. We are using province revenue for buying diesel fuel and electricity for wastewater treatment plant. Also, the procurement of wastewater treatment plant and salary for contact staffs are funded by local government revenue. Funding for the this year, we already proposed last year, for local government revenue, we asked cleaning devices (Informant 3)".

"Resource funding is only from local government revenue, no other funding. This local government funding manages both medical waste and daily hospital waste, and we still need more fund resources (Informant 4)"

Kwaingga hospital still needs more alternative funding for waste management since the only main funding resource is local government revenue. The fact is the budget that hospital asked to the local government is not same as the realization. Local government only gave $70 \%$ from budget that hospital proposed. This causes inadequate of funding for direct cost for buying facilitations, operational cost, and indirect cost such as conducting training for sanitarian staffs and cleaning services.

"The reality is this hospital every year needs 20 billion rupiah, and this requirement to make all activities run effectively. However, in fact hospital Kwaingga only has given 13 billion rupiah. This 13 billion rupiah included operational cost for waste management, electricity, medicine, medical supplies, and fuel for official vehicles. Therefore, we reduced the operational cost for diesel fuel for incinerator and we are economized spending electricity, so sometime medical waste is burned at temporary landfilled (Informant 4)"

"There is no fund to conduct training, only fund for official travel, and this is for senior employees. The budget that we asked whittled down" (Informant 3).

\subsection{Implementation of Standard Operational Procedure for Hospital Waste Management}

Kwaingga Hospital teams especially the director and sanitarian staffs have made efforts to manage hospital waste based on the standard operational procedure. From the process of sorting the waste from every room, frequent carried of medical waste and daily waste and carrying to temporary landfilled that already provide at the hospital back yard, running of wastewater treatment plant, using of septic tank, and incinerator.

"The sorting of waste already meets the procedure because nurses have done it, however, the carrying is still mixed. The carrying of no medical waste to temporary landfilled every day, and it is every 8 am morning" (Informant 2).

Waste management is already meets Standard Operational Procedure, however implementation in the field has found many obstacles (Informant 4).

There are several steps that already done based on the standard operational procedure such as sorting of waste from every room, carrying medical waste and non medical waste from rooms to the temporary landfilled, frequent burning the waste manually or with incinerator. Even those already conducted but there are still many steps that did not meet Standard Operational Procedure such as mixing the needless with other kind of waste, which is very dangerous. If incinerator cannot run, needless accumulated in the temporary landfilled. In addition, another problem is sanitarian staffs and cleaning services did not use selfprotection devices because of low of self-awareness and lack of monitoring from leaders.

Needless still accumulating, incinerator already three months did not use. There is barrier for liquid waste that is electricity cost. Pulse for electricity is very quick to run out. Also, bottom for setting the lab to septic tank was broke, and we have tried to fix it (Informant 1).

Staff only used gloves, but they did not use facemasks and also they did not use shoes boot (Informant 2).

\subsection{Factors that Restricting the Implementation of Standard Operational Procedure for the Hospital Waste Management}

There are several barriers in implementation of standard operational procedure and hospital waste management such as supporting equipment that rarely to operate due to limited operational cost for example limited cost to buying diesel fuel to run the incinerator, an expensive electricity cost to run the water waste treatment plant, and the landfilled burning that cannot destroy needless. Also, the sorting of hospital waste between medical waste and non medical waste from room to room is already fit with the standard operational; however, sometime cleaning services did mistake regarding sorting the waste and mixed this both type of waste. This is because there is no training among cleaning services and limited monitoring from hospital director and staffs that responsible for monitoring.

Sometime needless also mixed inside. Obstacle regarding collecting the waste is sometimes a staff mixed between medical waste and non-medical waste even we already separate it from room. This did not fulfill the standard operational procedure (Informant 1).

We have incinerator. We were rarely using it because it is very demanding and not economized for diesel fuel used. We more use manual way with burning it at temporary landfilled. We have Waste water treatment plant but the problem is we need more fund for paying electricity, so the waste water treatment plant runs just 4 hours per day (Informant 4).

The barrier also comes from limited staffs where number of cleaning services is limited. Kwaingga Hospital needs 20 staffs but Kwaingga Hospital only has 10 staffs. Then 
sanitarian staffs that involved 6 sanitarian are all women and based on the interview they need male sanitarian professional especially for waste water treatment plant and incinerator and also for carried the hospital waste from temporary landfilled to incinerator.

We need more male staffs, especially for carry the medical waste to incinerator. We have 6 sanitarian staffs and they are all women (Informant 1).

The implementation of standard operational procedure and the waste management inhibit by funding, for instance the construction of final permanent hospital landfilled needs money then staffs training also needs funding. Similarly, Kwaingga hospital really needs operational cost for wastewater treatment and incinerator and budget for sanitarian staffs incentive, so their performance increased. Also, cleaning services that want their salary improves. Another cost are needed such as budget for buying truck for carry the hospital waste to district permanent landfilled and also for buying the destroyed needless equipment.

We don't know where we can get the budget for buying diesel fuel. Budget from treasurer states that cost for diesel fuel is not budgeted and sometimes there is no money (Informant 3).

Document for Budget Realization (DPA) always has miss realization, another word district did not give money according on budget that we asked for all aspects. Proposal that we proposed did not fit with the funding that we get. This is not only for hospital waste but also for medicinel drugs expenses (Informant 4).

Currently, there is weak teamwork among institutions for waste management at Kwaingga Hospital and there is no frequent report regarding waste management to Environment district office. In addition, in order to make final permanent landfilled, Kwaingga Hospital needs partnership with district office government. According to the Kwaingga Hospital Director, they need monitoring and coaching from Environment District Office.

Implementation does not match with standard operational procedure, and there is no monitoring from Environmental Office. There is no partnership with Environmental Office (Informant 4).

We need teamwork cross institutions for medical waste management and we also worry if this hospital waste become a source of diseases to community. Therefore, we really put attention to the process of burning the waste and we put efforts to keep this hospital waste not contaminated and messed the area outside of Kwaingga Hospital, so it will not bother community around (Informant 4).

\section{Discussion}

Kwaingga Hospital needs more staffs for medical and nonmedical waste management because the number of stuffs is inadequate. This is similar with the study from Oli et al, (2016) this study states that for staff problems such as limited quantity and limited capacity must solve with training and involved the in to seminars in order to educate the sanitarian workers and cleaning services. This training should be topic about hospital waste management Standard Operational Procedure and Self-protection devices. Poor medical waste management will cause nosocomial infection in the hospitals [13].

Another problem in Kwaingga Hospital waste management is lack of supporting facilities such as machine to destroy needless and final permanent landfilled; it only has temporary landfilled and throwing needless at temporary landfilled at hospital backyard. These problems can cause health problems to community and economic problem to hospital its self such as transmission diseases, environmental pollution, and will lead to economic loss for hospital due to injury or unhealthy environment at hospital [7]. There is report from developing countries that many needle stick injuries in the handling hospital waste remained unreported and unregistered [1]

In Kwaingga Hospital also has poor segregation practice where staffs still mixing hazardous waste with general waste. Head of Kwaingga Hospital said that they need coaching from Environmental department. This is because poor controlling from head of waste management division and head of Kwaingga hospital. According to previous study, there is lack of law enforcement in hospital also in public in some of Asian countries [3].

Among sanitarian workers in Kwaingga Hospital, they only use glove when they work; they do not use facemask and boot due to low self-awareness and weak monitoring. According to regulation from Ditjen P2MPL, Indonesia Ministry of Health, Year 2004, the standard for selfprotections are using helmet, mask, eyes protection, long clothes, plastic apron/ industry apron, boot, and special gloves. Those self protections must be used by cleaning service and sanitarian staffs especially who for incinerator and temporary landfilled in order to decrease incidents in working. Also, they need to be trained about how to use and how to report if there is a mistake and damage [2].

Current study in Indonesia has found that physicians have good knowledge about medical waste management compared to non-physician. This study found that $84 \%$ physicians understand well about medical waste management and only $52 \%$ non-physicians including nurses, midwife, pharmacy, and analysts who knows about medical waste management. The questioner is about chemical waste, segregation practices and color-coding. That is why this study recommends the important of training for improving healthcare workers knowledge and attitude toward medical waste management in order to avoid nosocomial infection and occupational accident [10].

Incinerator in this hospital was rarely to use since its structure is bad; and it has potential to explode. The pillar of this incinerator was made from wood and according to the interview with the sanitarian workers; they are scared that the pillar might be burned. Similar with study from Cameroon where it found that from several regions in Cameroon, only four healthcare facilities that have incinerators and all those incinerators did not meet the required standard. The function 
of incinerator is to destroying high volume of medical wastes; however, its construction must be concerned because it can cause air pollution, and if it does not meet the guideline, it can cause underground water pollution [4]. This case might be caused by lack of investment or limited funding support [17].

The study in Kwaingga Hospital also found that there is problem about limited budget that cause incinerator cannot operate frequently and waste water treatment runs only four hours per day due to expensive diesel fuel and electricity power. Moreover, Kwaingga Hospital cannot able to buy the machine for destroy used needless and cannot built permanent final landfilled that fit the Standard Operational Procedure from Indonesia Ministry of Health. Those all because realization of the proposal of budget did not come same as the budget planning that Kwaingga Hospital asked to District Government Revenue. World Health Organization states that treatment and management for hospital medical waste is up to 8 times more expensive that daily non-medical waste management in hospital. However, this still must be conducted; waste management planning and monitoring in hospitals are necessary in order to decreases risks from hospital waste [7].

Similarly, study from Gai et al (2009) has found same issues; this study found that there are several hospitals in remote area in Shandong Province China have financial problem for medical waste management. This study states that in order to implement proper hospital waste management, government must give financial support and administrative monitoring [6]. Beside lean on local government revenue, Kwaingga Hospital needs financial support from national revenue and donor from other department such as Environment Department especially for providing equipment and technology for this medical waste management.

Medical waste management in Kwaingga Hospital does not have division for problems regarding occupational health and safety, lack of monitoring for self-protection, and sometimes-daily waste and medical waste are mixed. According to study from Ivana et al. there are several facilitations that hospital must provide to boost the occupational health and safety such as self protection devices, separation of medical waste and non medical waste, communication system using line telf, safety sign, monitoring for self protection, incident report, and hazard identification. There must be a unit that has a function to solve problems regarding occupational health and safety [8].

Kwaingga Hospital must review and edit its standard operational procedure for hospital waste management; it must refer to Indonesia Health Ministry regulation number 1204 year 2004 and also government regulation number 18 year 1999. These case same as the government hospital in Java Province Indonesia, General Hospital Regional Blambangan, Banyuwangi. Even it is located in big city not remote area, this hospital still did not meet Indonesia Health Ministry regulation number 1204 year 2004 [9].

The government regulation number 18 year 1999 divines hazard waste that dangerous for environment, ecosystem and human health. Medical waste is one of hazard waste. The hazardous waste includes infectious waste, pathology waste, sharp waste, pharmacy waste, cytotoxic waste, chemical waste, and radioactive waste. Therefore, hospital waste in Kwaingga Hospital must refer to several regulations about medical and hazardous waste, one of them is Health ministry regulation number 1204 year 2004 [16].

\section{Conclusion}

Human resources for waste management at Kwaingga Hospital is still inadequate from quantity and quality, they only have 6 sanitarian staffs; also they are lack of training where the last training was four years ago. Kwaingga Hospital already tried to full fill the Operational Standard Procedure, however; there is limited operational cost to run the incinerator and water waste plan. There is no machine for destroying used needles; there is no device for room sterilization; and there is problem for segregation practices. The incinerator in this hospital also did not meet required standard since its pillar made from wood not iron. Wastewater plan was bought from regional revenue, however; this machine needs operational cost for paying electricity and diesel fuel. Salary for cleaning services and contract staffs also come from regional revenue/local government revenue, but this fun allocation is not enough to paying all hospital needs. Realization from regional revenue is only $70 \%$ from the proposal of budget that hospital asked. There is still several requirements from Operational Standard Procedure that did not implemented such as sanitarian staffs did not use protection equipment, there is no final landfill that far from community and hospital, and there was still used needless stacked up at hospital temporary landfill.

\section{Acknowledgements}

Author hopes that Governor and Regent increase funding from district/regional revenue and province revenue for hospital waste management at Kwaingga hospital. Also, The head of Kwaingga Hospital must review its standard operational procedure for hospital waste management and refers it to the government regulation number 1204 year 2004. The head of Papua Environment Department must do intense monitoring for hospital waste management and finding aids to provide equipment for this medical waste management.

\section{References}

[1] Ali et al, (2017), Hospital Waste Management in Developing Countries: A Mini Review. International Solid Waste Association, Vol 35; 581-592.

[2] Asmarhany Chandra, (2014), Medical Waste Management at Kelet Public Hospital District Jepara. Public Health Department, Semarang State University: Semarang. 
[3] Das and Biswas (2016), Awareness and Practice of Biomedical Waste Management among Healthcare Providers in A Tertiary Care Hospital of West Bengal, India. International Journal of Medicine and Public Health, Vol 6, issue 1.

[4] Dzekashu et al (2016), Medical Waste Management and Disposal Practices of Health Facilities in Kumbo East and Kumbo West Health Districts, Journal of Environment Health Science, Vol 2 (6); 1-9.

[5] Frumkin Howard (2005), Environmental Health From Global to Local, Jossey Bass, San Francisco.

[6] Gai et al, (2009). Hospital Medical Waste management in Shandong Province China, International Solid Waste Association, Vol 27 (4); 336-342.

[7] Gusca et al,. (2015). Assessment Method of Healthcare Waste Generation in Latvia and Kazakhstan. Energy Procedia, 72; 175-179.

[8] Ivana et al,. (2014). Analysis of Hospital Management Commitment toward Occupational Health and Safety at Prima Medika Hospital Pemalang, Journal of Public Health, Vol 2, number 1 .

[9] Line and Sulistyorini, (2013), Evaluation of System Waste Management at Blambangan Public Hospital Banyuwangi, Journal of Health Environment, Vol 7 (1); 71-75.

[10] Maharani et al, (2017). Knowledge and Attitude of Healthcare Workers toward Medical Waste Management at Hospital in Bandung City, Health System Journal, Vol 3 (2); 84-89.
[11] Maulana et al,. (2015). Medical Waste Management at Yogyakarta Hospital. Journal of Public Health, Vol 8, number 01 .

[12] Notoatmodjo, (2011). Kesehatan Masyarakat Ilmu dan Seni, Rineka Cipta, Jakarta.

[13] Oli et al,. (2016). Healthcare Waste Management in Selected Government and Private Hospitals in Southeast Nigeria, Asian Pacific of Tropical Biomedicine, 6 (1); 84-89.

[14] Omar et al,. (2012), Clinical Waste Management in District Hospitals of Tumpat, Batu Pahat and Taiping, Journal of Social and Behavioral Sciences, Vol 68, 134-145.

[15] Pertiwi et al.(2017). Evaluation of Hazardous Waste in Roemani Muhammadiyah Hospital Semarang, Public Health Journal, Vol 5 (3), 420-430.

[16] Saragih and Herumurti, (2013). Evaluation of Incinerator Function for Destroying Hazardous Waste in National Soldiers Hospital Doctor Ramelan Surabaya, Journal of POMITS Technic, Vol 2 (2); 138-143.

[17] Shalini et al, (2012), Evaluation of Bio-Medical Waste Management Practices in A Government Medical College and Hospital, National Journal of Community Medicine, Vol 13; 80-84. 